\title{
EVOLUTION OF LATERAL DESIGN IN THE UNITED STATES
}

\author{
NATHAN A. HICKS ${ }^{1}$ PE, SE AND EDMUND P. MEADE ${ }^{2}$ PE, FAPT \\ ${ }^{1}$ Silman - 1053 31st Street, NW - Washington, DC 20003 - United States \\ e-mail: hicks@silman.com, www.silman.com \\ ${ }^{2}$ Silman - 32 Old Slip, $10^{\text {th }}$ Floor - New York, NY 10005 - United States \\ email: meade@silman.com, www.silman.com
}

Keywords: Lateral, Seismic, Wind, Earthquake

\begin{abstract}
This paper explores the design profession's evolving understanding of lateral design. It shows how the United States building codes' handling of seismic and wind forces has changed over time, often in response to extreme events or technological developments. Prior to the early 1900s most buildings were designed without an explicitly defined lateral force resisting system. Up to that time period earthquakes and strong wind events produced little in the way of code requirements to address lateral forces. It was the advent of steel and high-rise construction in the late $19^{\text {th }}$ Century that triggered a need to consider lateral loads. During the early $20^{\text {th }}$ Century little consensus existed regarding the lateral forces that needed to be resisted. Wind loading provisions began appearing in the codes of large cities in the early 1900s, but it would not be until the 1930s that seismic provisions started to be codified, and then only in California. Throughout the $20^{\text {th }}$ Century significant lateral events have continued to expose vulnerabilities that have been subsequently addressed with changes in construction detailing and code restrictions. In the mid-1900s regional building codes developed, focusing on the lateral hazards present in their locality. By 2000 these regional codes were replaced by a national code, and lateral design has now started to shift from prescriptive requirements towards performance-based design. This paper will help structural engineers better understand the historic building stock by exploring how lateral design has evolved in the US over the last hundred years.
\end{abstract}

\section{INTRODUCTION}

Lateral design of buildings is a relatively new field within structural engineering. Until recently, building codes in the United States and throughout the world included few, if any, requirements for wind and seismic. In the early 1900s the education of engineering students included little on the effect of wind on structures, and knowledge about earthquakes was very limited. When looking at earthquakes and extreme wind events, it is interesting to examine why lateral design took so long to evolve. Part of the reason is the perceived risk, which is tied to the fact that such events occur infrequently. While gravity loads are always present, a significant lateral load event might have a mean return period of over a hundred years. The longer return interval means a large hazard database does not exist, and lessons learned were often forgotten. "Gravity was always available to test construction and did so whether the builders wanted their structures tested or not as they assembled their pieces. 
Refinements...incrementally proceeded as an applied research by-product of construction. Even if one way of arranging material was a little more earthquake resistant than another there was usually no feedback for the building, only an earthquake test that might happen a few hundred years later." 1

Unraveling the history of lateral design is a complex task - it comes to us as a web of events, technological advances and contributions from across the engineering community. Although the understanding of wind and earthquakes relies on contributions from individuals around the world, this paper is focused on its evolution in the United States. The purpose of this paper is to examine how lateral design for buildings has changed over time and give examples from our own work on existing buildings.

\section{EARLY HISTORY}

Before the mid-1800s attempts to understand the source and nature of lateral loading were limited. Regardless of the designer's intent, gravity systems served to resist lateral forces. While it is tempting to give credit to past engineers for development of lateral resistant designs, it was often an unknown benefit of common construction practices. As an example, Fort Point in San Francisco survived the 1906 Earthquake with little damage. This was a secondary benefit of the extremely thick masonry walls common to fort construction. The Fort was designed to provide protection against attack, not protection against earthquakes. ${ }^{2}$
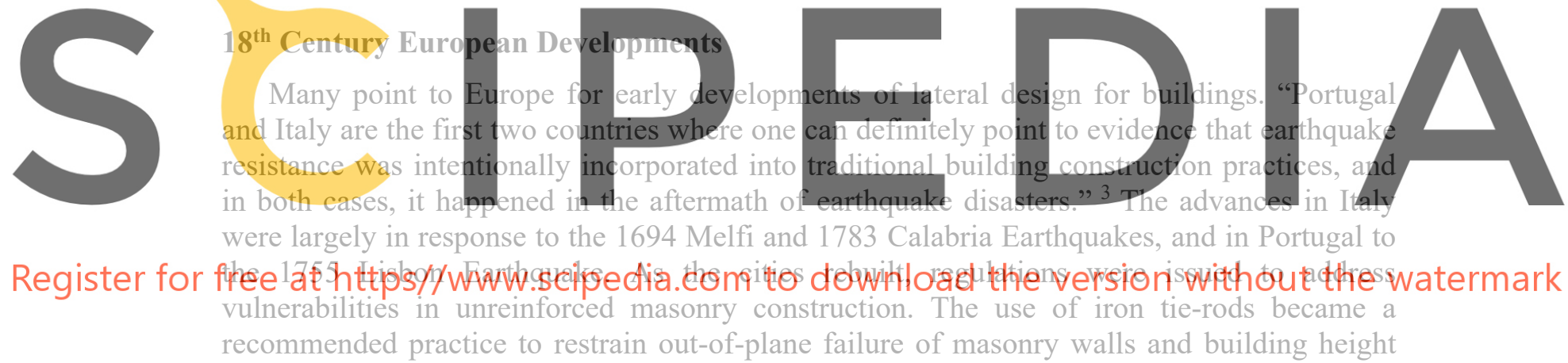

restrictions were passed. In both regions a construction system using heavy timber frames with masonry infill was introduced. The construction was called "casa baraccata" in Italy and "gaiola" in Portugal. ${ }^{4}$ In our work in the US, we often come across similar wood frame and masonry infill construction from the $17^{\text {th }}$ and $18^{\text {th }}$ Centuries, which is known as brick noggin. What makes Italy and Portugal unique is that the wood frame was clearly intended as a seismic retrofit, whereas in the US, the system appears to have developed with less consideration of lateral loads.

\section{New Madrid Earthquakes}

In the winter of 1811 and 1812, a series of three earthquakes were centered around New Madrid in what is now Missouri. Prior to the $20^{\text {th }}$ Century these events were the most powerful earthquakes in recorded US history. The entire town of New Madrid was destroyed, but the effects were felt wider, as chimneys collapsed as far away as Cincinnati, and ground shaking could be felt in Boston. ${ }^{5}$ While New Madrid was an incredibly powerful earthquake, it had little impact on advancing earthquake engineering in the US. Its epicenter was in a 
relatively undeveloped region of the young nation, so it is not surprising that no building regulations came about as a result.

\section{Early US Building Codes}

Building regulations, in modern form, did not exist prior to the mid-1850s in the US. When major cities started to establish building codes, they were focused on the frequent hazard of fires and silent on the infrequent hazard of lateral events. "Loss of life and property in several fires led to widespread support for development and enforcement of building standards. The earliest building controls were enacted at the local level...urged by insurance companies as a way of controlling financial loss." 6 In the US, some of the first building regulations arose in cities like Baltimore in 1859, New York with the 1867 Tenement House Act, and in 1875 in Chicago following the 1871 Great Chicago Fire. ${ }^{7}$

\section{LATE $19^{\mathrm{TH}}$ CENTURY}

At the beginning of the 1800 s, timber framing and unreinforced masonry comprised almost all structures in the US. In the mid-1800s wrought iron and cast iron slowly started to gain use in buildings as they became more economical. It was at this same time that reinforced concrete construction also started to develop. Finally, in the late 1800s mild steel started to take the place of iron, ushering in a new era of construction. ${ }^{8}$
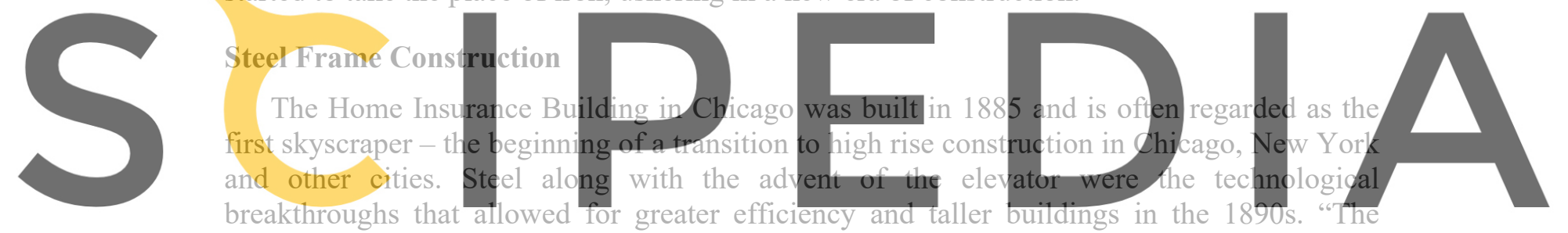

ultimate step in the creation of the modern skyscraper came with the construction of the

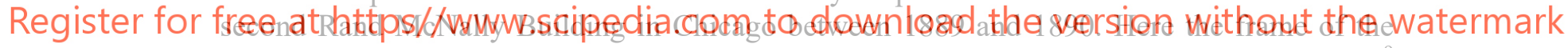

high office building was wholly freed from its masonry adjuncts and built entirely of steel." 9

Global annual output of steel output grew exponentially between 1870 and 1900, from 0.5 to

28 million tons. ${ }^{10}$ As buildings in the US abandoned their thick masonry walls and grew taller, engineers realized they could no longer ignore the need to rationally respond to wind and seismic lateral loads.

\section{Beginning of Wind Design}

Builder handbooks from the time period note that "when office and other building of six to ten stories were built with solid masonry walls no attention was paid to the lateral strains due to wind pressure, except, perhaps, to make the walls and partitions a little heavier. And as such buildings were seldom built of a less width than 50 feet, no other precautions were really necessary, for whenever buildings of ordinary construction have been blown down, it has generally been due more to a poor quality of work...rather than to faulty design." ${ }^{11}$ The consideration of wind loads was so foreign in these early years that a view persisted through the early 1890s that high-rise buildings with "sufficient" plan dimensions relative to their height did not need an explicit lateral force resisting system. Many early high-rises were 
designed without wind bracing, and our office has worked on several such buildings throughout the Midwest and Northeast. Luckily, the early skeleton frame structures often still had infill masonry between frames that stiffened the structure and improved lateral performance. $^{12}$

Finally, in the late $19^{\text {th }}$ Century there was an acknowledgement that high-rise structures needed to consider wind loading. A guidebook from the turn of the century puts it well, "the modern steel buildings are built to such great heights, especially in proportion to their width, and are so destitute of ordinary means of resisting wind pressures, such as solid walls and partitions, that some efficient means of bracing the steel frame would seem to be a matter of necessity. As a matter of fact, few if any skeleton steel buildings are now being erected without some provisions for bracing the steel frame independent of the partitions. In some buildings these provisions consist merely in using girders built of angles and plates of good depth and use of riveted connections... while in others heavy sway-bracing, knee or portal bracing, or both combined have been employed." 13

Steel manufacturers started to publish recommended wind bracing details, and common builder guidebooks printed tables correlating wind velocity to pressures (see Figure 1). Much of the early research into wind design was taken from the railroad industry and the field of bridge design. While there was a diversity in practice for buildings, bridge engineers were designing their structures to resist wind loads on the order of 30 to $60 \mathrm{psf}^{14}$

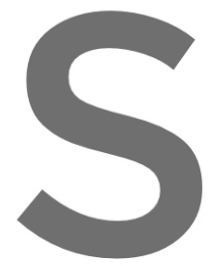

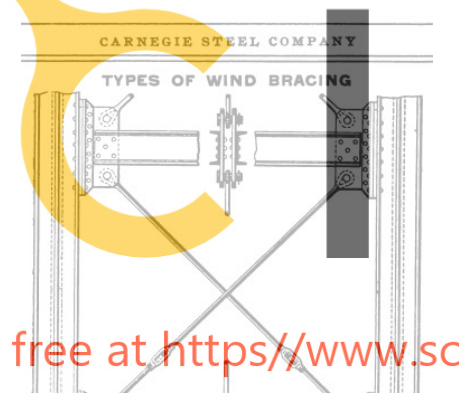
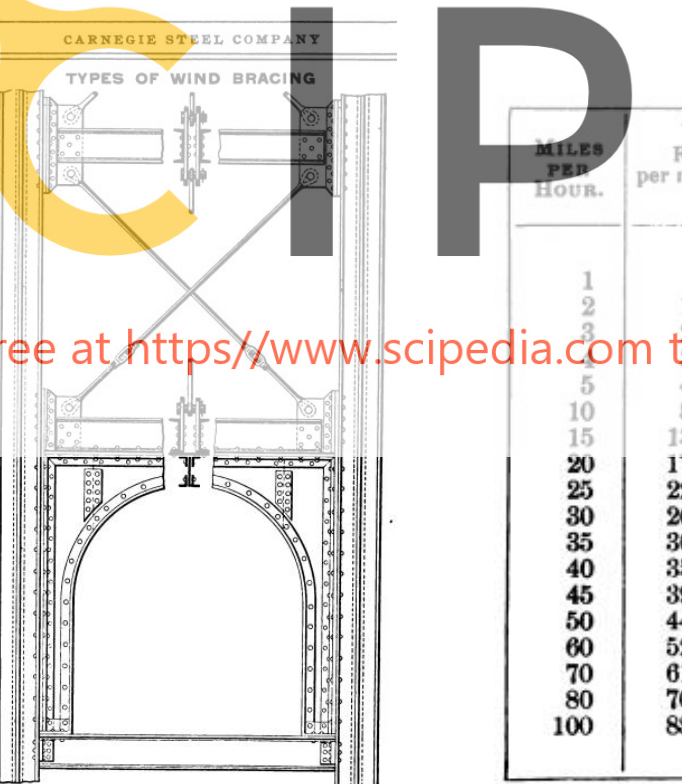
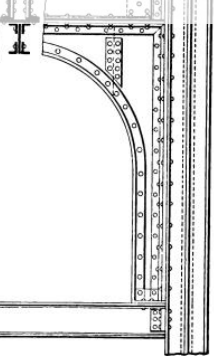
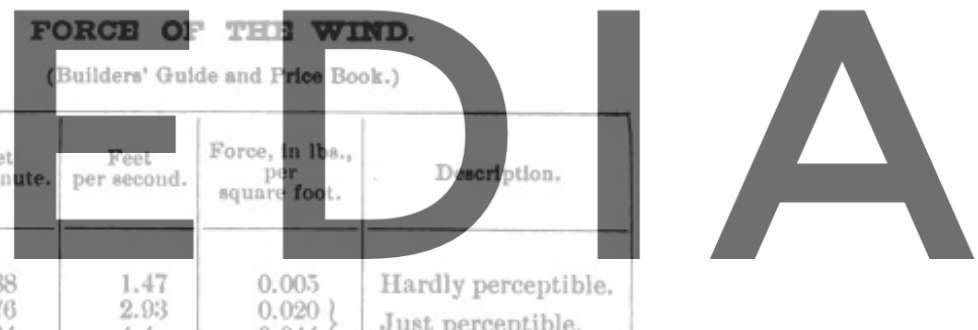

the version without the watermark

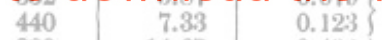

\begin{tabular}{l|l}
880 & 14.67 \\
1320 & 22
\end{tabular}

1320

1760

2200

22

29.3

26.6 .

44

51.3

58.6

66

73.3

10:2.7

102.7
117.3

146.6

$0.492\}$

1. 107

1.970

$3.067\}$

$4.429\}$

$6.027\}$

7.870

$9.900\}$

12.314

17. 7333

24.153

$31.4 ! M)$

$49.200\}$

Pleasant breeze.

Brisk gale.

High wind.

Very high wind.

Storm.

Great storm.

IIurricane.

Figure 1: Typical Wind Bracing Details (left) and Wind Table (right) ${ }^{15}$

\section{The West Coast}

In most of the country, high-rise construction focused on wind, but on the West Coast earthquakes presented a far greater risk. While earthquakes were known to occur in California, they did little damage given the sparse population. While seismic concerns had caused investors to initially balk at high-rises, several were built in San Francisco by the late 
1890s. "An earthquake shock which disturbed that locality in the spring of 1898 was reported to have caused the buildings to rock and sway but to have left them practically uninjured." 16 Small steps were made to improve lateral seismic loading resistance of buildings in the later part of the 19th Century. For instance, following the 1868 Hayward California Earthquake, changes were instituted to load-bearing masonry walls (built prior to the introduction of steel and concrete frame buildings). Some of these buildings performed well during the 1906 San Francisco Earthquake. ${ }^{17}$

\section{Charleston Earthquake}

The most notable seismic event in the US from the latter half of the $19^{\text {th }}$ Century was the 1886 Charleston Earthquake in South Carolina, which is still the largest record seismic event for the Eastern US. Over 100 buildings were destroyed, and 90 percent of the buildings in the city were damaged. Nearly every chimney in the city collapsed and ground shaking was felt as far away as St. Louis, Chicago and Boston. ${ }^{18}$ The Charleston Earthquake represented the first well studied earthquake in US history. The insurance industry went building by building documenting observed damage, and Clarence Dutton of the US Geological Survey produced a detailed report on typical failure mechanisms. Unfortunately, the Charleston Earthquake and Dutton's work did little to drive change in the US or advance earthquake engineering. ${ }^{19}$
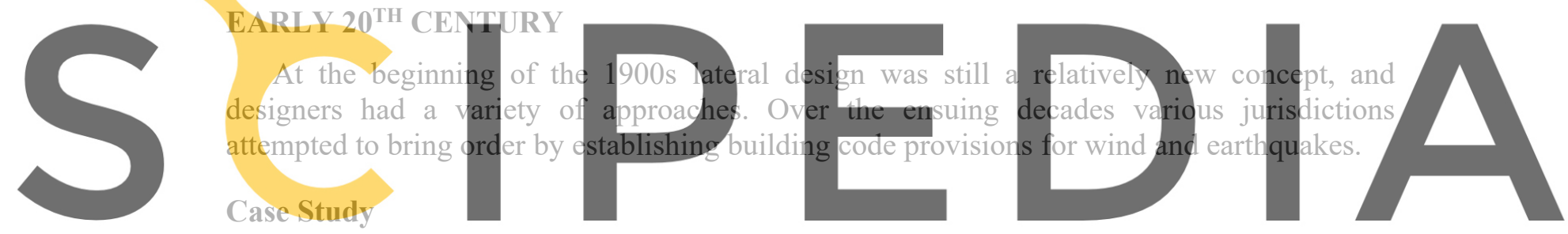

Our office recently completed the structural engineering design for the exterior restoration

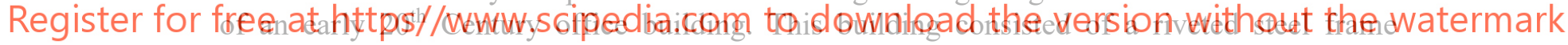
substantially braced by its exterior load-bearing masonry walls. Based on our review of existing drawings and investigations, we determined that the steel frame provided limited lateral resistance due to the modest steel connections. No braced frames were present and while the connections were well detailed, they had limited ability to act as a moment frame. The building is surrounded by an exterior masonry wall that consists of exterior architectural terra cotta, six to seven wythes of brick, and interior architectural terra cotta infill. Compared to the stiffness of the masonry walls, the stiffness of the steel frame is almost negligible.

We evaluated the condition of the masonry walls by performing selective probes and nondestructive testing techniques. We used site-specific seismic force coefficients developed by geotechnical engineers and the known characteristics of the building to begin our analysis. Using code-prescribed formulas, we evaluated the effect of the removal of four to eight inches of exterior terra cotta on the shear capacity of the walls. Our structural evaluation revealed that with removal of the selective amounts of exterior terra cotta there would be a nominal, acceptable increase in the maximum stresses within the masonry wall. Seismic loading controlled over wind loading due to the weight of the building. Based on these findings, no temporary or permanent seismic reinforcement was required to accommodate the proposed alterations to the exterior masonry walls. The removal and restoration of the architectural 
exterior terra cotta proceeded without concern on the lateral load carrying capacity of the structure. See Figure 2 for a depiction of a typical cross section through the exterior wall and steel frame, and a view of the tightly integrated exterior terra cotta and backup brick masonry.

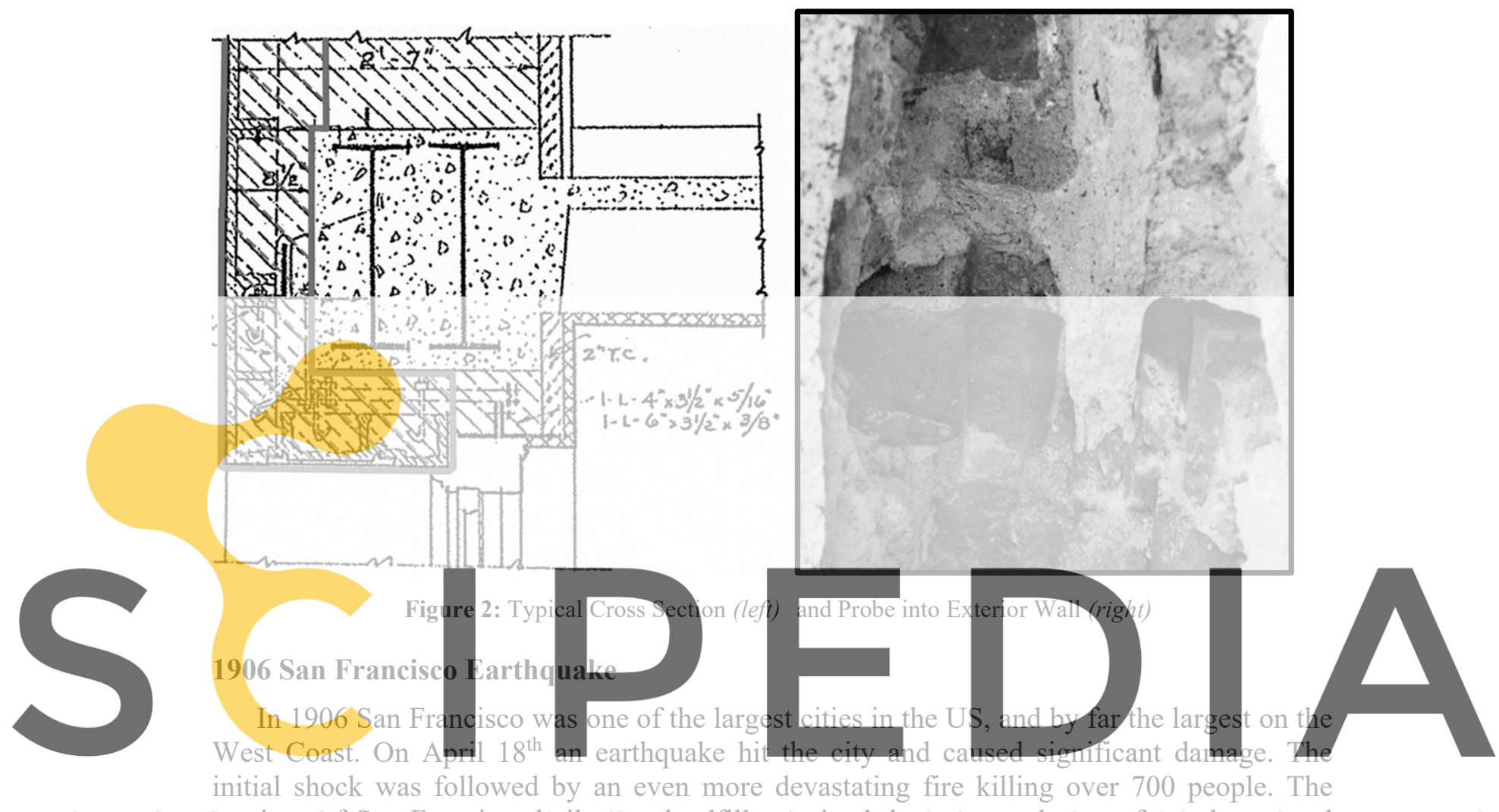

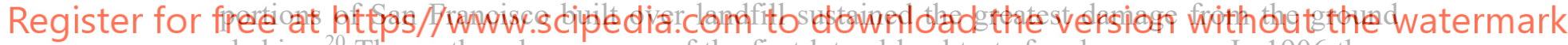
shaking. ${ }^{20}$ The earthquake was one of the first lateral load tests for skyscrapers. In 1906 there were over two dozen steel frame buildings in San Francisco, and none collapsed. There was damage at the exterior infill masonry walls and interior masonry partitions, but overall, the steel frames performed relatively well. The performance led to a long-held belief these systems were earthquake resistant. ${ }^{21}$ With these early high rises, San Francisco engineers had put thought into how to resist seismic loads. The beam-column joints were heavily riveted and many of the wind bracing techniques used in Chicago and New York were adapted for San Francisco. While there were no mandatory seismic provisions at the time, most engineers in the area used a high wind loading of 30 psf as a substitute for seismic loads. ${ }^{22}$

Although the 1906 Earthquake is still perhaps the most notable seismic event in US history, its immediate impact on structural engineering was minimal. On the national scale, earthquakes were viewed as a California problem. Even on the local scale, seismic loading recommendations were lowered from 30 to 15 psf to permit quick reconstruction. Unreinforced masonry construction, which had fared poorly, became even more prevalent across the city. ${ }^{23}$ A couple decades later "some buildings in San Francisco were designed with a seismic coefficient of $10 \%$...however, one contemporary of that time estimates that in the 1920 s a minority of engineers there computed any earthquake forces." 24 


\section{Code Provisions for Wind}

At the turn of the century, building ordinances in larger cities started to bring uniformity to wind design. To illustrate the earlier diversity, an engineer from the time mentions a 17story building in New York with a lateral force resisting system that relied on interior terra cotta partitions, whereas a similar 17-story building a couple blocks away was built at the same time with significant steel sway bracing. ${ }^{25}$ By the early 1900 s both Chicago and New York building codes required a wind pressure of $30 \mathrm{psf}$ for buildings of skeleton construction. Provisions also required the engineer to ensure the overturning moment due to wind did not exceed $75 \%$ of the resisting moment due to dead load. ${ }^{26}$ Baltimore and Philadelphia passed similar laws shortly thereafter. By the 1920s most major US cities had wind ordinances and where they did not wind pressures of 20 to 30 psf were generally considered adequate. ${ }^{27}$

\section{Uniform Building Code}

In 1927 the Pacific Coast Building Officials adopted the Uniform Building Code (UBC). It quickly became the accepted standard throughout California and eventually the West. The first edition had seismic provisions, but these were optional and included as an appendix. The appendix was unique in that it applied a seismic coefficient rather than using wind pressures as a pseudo-seismic force. Engineers at the time argued that the "force of an earthquake shock depends on the mass of the building and its contents" 28 and pointed to the use of seismic

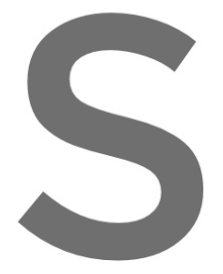
coefficients of $10 \%$ of gravity in Japan as an example. The 1927 UBC recommended a seismic coefficient of $7.5 \%$ of the bunding's weight, which varied slightly based on the site's soil type. It is deceptir included significan approach, which is live load. .

\section{Long Beach Earthquake}

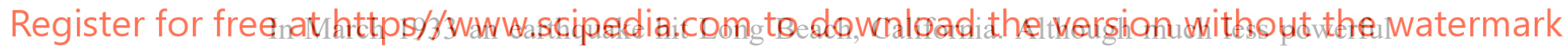
than the 1906 San Francisco Earthquake, it proved to be a catalyst for change. California was finally ready to implement seismic regulations. The Los Angeles Chamber of Commerce spearheaded an effort to ensure that earthquake resistant construction became the standard in California with new code requirements and limitations on unreinforced masonry construction. ${ }^{30}$ The 1933 Long Beach Earthquake eventually led to the Field and Riley Acts. These were statewide laws that applied to most structures other than single family residences. Like the 1927 UBC, these acts applied seismic coefficients of between $2 \%$ and $10 \%$ as a lateral load. They were the first codified examples in the US of varying lateral loads based on the site's soil type and the importance of the building occupancy. ${ }^{31}$

\section{MID 20 ${ }^{\text {TH }}$ CENTURY}

It was during the mid-20 $0^{\text {th }}$ Century that development of codes began to shift away from cities to model building codes for specific regions. In the West, the International Conference of Building Officials (ICBO) developed the UBC. In 1950 the Building Officials and Codes Administrators (BOCA) published a model code to serve the Midwest and New England regions. In the South, the Southern Building Code Congress International (SBCCI) published 
the Standard Building Code (SBC) in 1945. From a structural perspective, each of these model codes primarily focused on the hazards and lateral loads most common to their geographic area. The UBC emphasized earthquakes, and the SBC and BOCA emphasized wind. $^{32}$

In 1945 the first national standard for Minimum Design Loads in Buildings and Other Structures (ANSI 58.1) was developed. The standard was the precursor to the ASCE 7, which is still referenced for lateral loadings in the US today. The standard introduced several new concepts - wind pressure on a building surface increased with height, maps were included with recommended design wind velocities, and a minimum seismic force of 5 percent of dead load was recommended for all buildings (see Figure 3). ${ }^{33}$
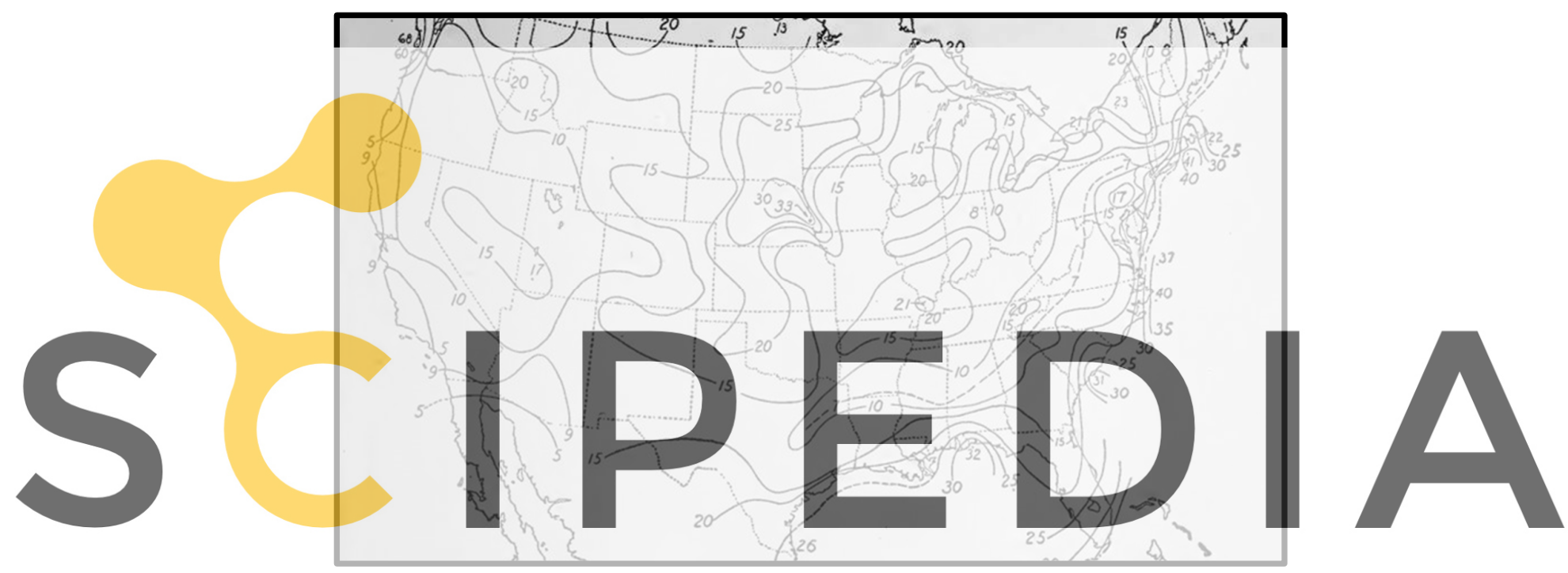

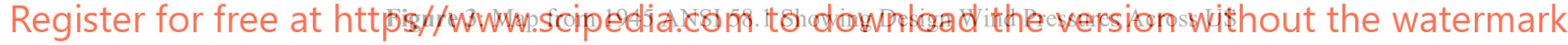

Jurisdictions had the freedom to adopt as much, or as little, of the model building codes as they felt to be appropriate. As a result of this freedom, large differences began to emerge in between the seismic provisions of Northern and Southern California. Many of the changes were quite forward thinking, but not universally adopted. The 1943 Los Angeles code lowered base shear as the height of a building increased, associating longer period structures with smaller seismic forces. In the 1949 many cities removed live loads from the effective seismic weight and started to use an inverted triangle to distribute seismic loads up the height of a building. In the 1950s certain jurisdiction required retrofit of unreinforced masonry buildings. These are a few of the examples, which eventually led the Structural Engineers Association of California (SEAOC) to develop the Recommended Lateral Force Requirements and Commentary, more commonly known as the Blue Book. For several decades this Blue Book would serve as the basis for seismic building codes across the US. ${ }^{34}$

\section{Florida Wind Standards}

As building codes in California led the way in seismic design, Florida building codes started to lead the way in wind. Between 1940 and 1970 several hurricanes, coupled with 
booming population growth in the state led to increased wind requirements. In most parts of the state the wind provisions were taken from the SBC, but in Dade and Broward counties, the South Florida Building Code developed with additional wind provisions to cover the higher risk. Florida codes were reactive and based on observed failures after hurricanes with requirements focused on the main wind force resisting system. ${ }^{35}$

\section{Alaska Earthquake}

The 1964 Alaska Earthquake is one of the most powerful earthquakes ever recorded. It hit a relatively undeveloped region but still caused substantial damage. The earthquake exposed previously unknown vulnerabilities with concrete construction. Specifically, it showed the need to strengthen connections at tilt-up construction and reinforcement detailing at concrete frames. The 1971 San Fernando Earthquake, while a much smaller at magnitude, highlighted similar lessons with concrete construction. ${ }^{36}$

By the 1960s and 70s ground motion records had started to accumulate. While codes at the time implied seismic accelerations on the order of $5 \%-20 \% \mathrm{~g}$, instrumentation showed accelerations over $100 \%$ g. The 1974 Blue Book stated that "design forces...are not to be implied as the actual forces to be expected during an earthquake. The actual motion generated by an earthquake may be expected to be significantly greater than the motions used to generate the prescribed minimum design forces." 37 The code was in effect relying on the dissipation of energy through inelasticity. This represented a large shift in thinking for
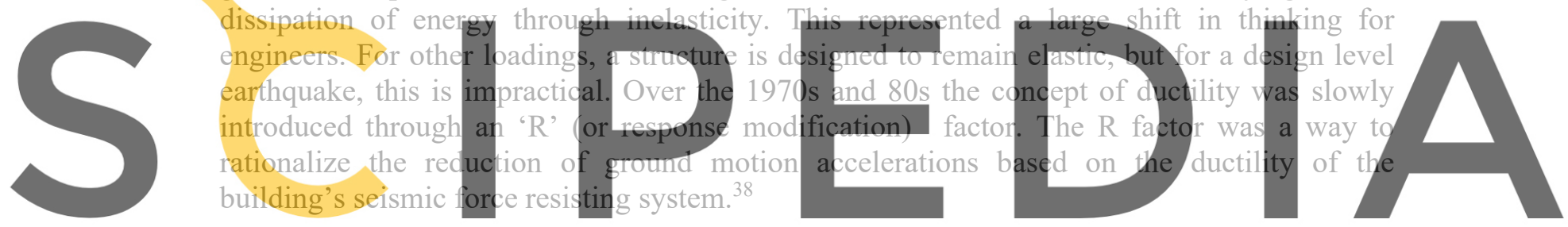

Register for RECENT HISTORY

RECENT HISTQRY
free at https//WWW.scipedia.com to download the version without the watermark

The two most prominent earthquakes in recent US history were the 1989 Loma Prieta and

the 1994 Northridge Earthquakes in California. These were the first significant tests of US seismic engineering in major metropolitan areas. While there were failures, the loss of life and structural damage were minor given the magnitude of ground motions. These earthquakes showed that when strong engineering measures are in place, it can mitigate much of the risk for extreme lateral events. Despite the relatively good performance of most structures, there were still some critical lessons learned that have been incorporated into the code. Specifically, during the 1994 Northridge Earthquake fractures were observed in several beam to column connections for steel moment frames. Subsequent research showed the need to improve detailing to ensure a strong column/weak beam response for moment frames. By forcing the yielding of the connection in the beam member, the overall system's ductility is improved, which has now become standard in high seismic regions. ${ }^{39}$

\section{Hurricanes}

Over the last 30 years hurricanes in Florida and the Gulf Coast provided valuable lessons for wind design. In 1992 Hurricane Andrew was the first major test for Florida following the 1970s population boom. Buildings did not perform as well as might have been expected. 
There were failures at gable end roofs, rooftop equipment, wood frames racking, and roof to wall, and wall to foundation connection issues. ${ }^{40}$ The storm also highlighted the vulnerability of building envelopes to wind-borne debris. Prior to the storm, there were no requirements for storm shutters protecting glazing, which contributed to the high cost of the hurricane. The poor performance led to the first statewide building code and significant changes in loading and detailing requirements for wind. ${ }^{41}$

Between 2004 and 2005 a series of powerful hurricanes, including Charley, Frances, Jeanne, Katrina and Wilma, all made landfall in the Southeast. Much construction had taken place under codes written in the 1990s, so this increased storm activity gave engineers an opportunity of evaluating the effectiveness of new code requirements. The storms highlighted the need for additional mitigation measures to address building envelopes, roof soffits, and the performance of essential facilities. ${ }^{42}$

\section{Moving Forward}

For much of the $20^{\text {th }}$ Century there were three predominant model building codes in the US. Beginning in the 1980s efforts were made to start improving the consistency between the UBC, BOCA and SBC. Finally, in 2000 the International Code Council (ICC) published the International Building Code (IBC), which has since been updated every three years. The IBC represented the first national building code and brought a uniformity to lateral load

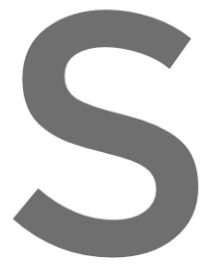

design that had been lacking with the regional codes. ${ }^{43}$ No longer could the West Coast

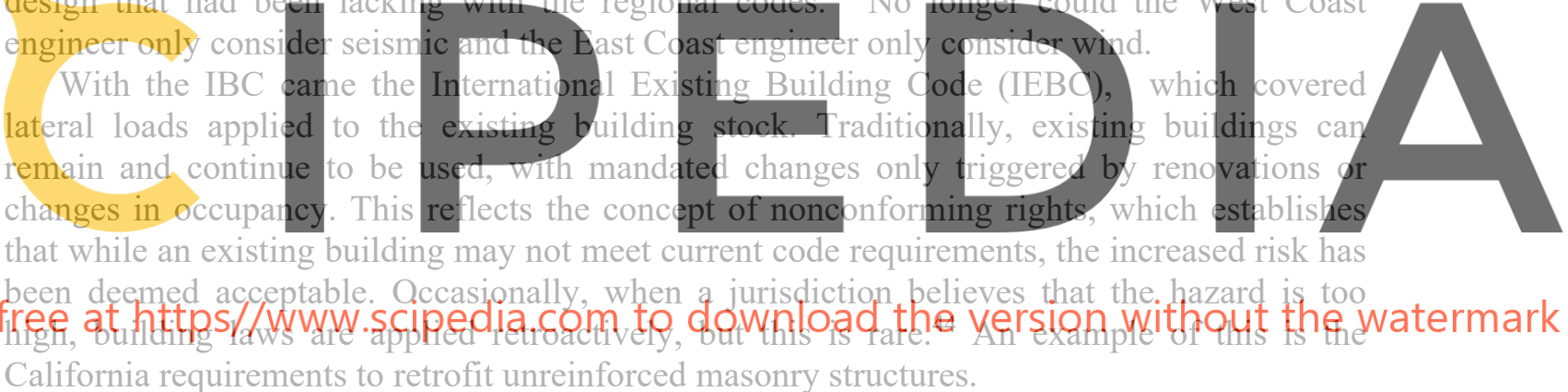

Advances in computing technology have started to change the way existing buildings, and all structures, are analyzed for lateral loads. We are now able to capture nonlinear behavior of building materials, create finite element models, and apply dynamic loadings, such as earthquake time histories. As a result, the industry has started to slowly shift away from prescriptive requirements to performance-based design. For lateral loads, the idea is to pair an established hazard level (based on a recurrence interval) with the desired performance following the hazard (collapse prevention, life safety, immediate occupancy, etc.). This permits the design of new buildings or reinforcement of existing buildings with an understanding of the risk of casualties, occupancy interruption, and economic loss that may occur as a result of a design-level wind or seismic event. ${ }^{45}$

The benefits of performance-based design were highlighted following the 2011 Mineral Earthquake centered in Virginia near the nation's capital. The seismic event was felt throughout East Coast, and while not as large as other events highlighted herein, hit a region unaccustomed to seismic events with far more historic unreinforced masonry structures. Our firm studied numerous parapet and chimney collapses, along with several instances of failed 
facades due to poor connections with the backup structure. Some of the most notable damage included tall, slender unreinforced structures such as the spires and towers on the Smithsonian Castle. Significant damage was documented in the decorative plaster ceilings at Washington Union Station. While little damage was reported to global seismic force resisting systems, the Mineral Earthquake highlighted the vulnerabilities of non-structural components, which in low to moderate seismic regions are often left unchecked by prescriptive codes.

\section{CONCLUSION}

Even today the profession learns something new after each major event; strong evidence that the field has yet to stabilize upon a singular, broadly recognized approach towards lateral design and construction standards. Our understanding of lateral loads and how to resist these extreme events in our building design continues to evolve. As structural engineer George Housner once stated, engineering for lateral loads "is a $20^{\text {th }}$ Century development, so recent that it is yet premature to attempt to write its history. ${ }^{46}$ While perhaps too soon, the hope is that this short history has helped to explain how lateral design has evolved in the US, and that by understanding that history, we can make more informed decisions about how to move forward and how to address the past.

\section{REFERENCES}

[1] Reitherman, Robert K. Earthquakes and Engineers: An International History. ASCE Press, Reston (2012) p 46.

[2] Reitherman. Earthquakes and Engineers. p 47.

[3] Reitherman. Earthquakes and Engineers. p 85.

[4] Reitherman. Earthquakes and Engineers. p 85-93.

[5] American Standard Building Code Requirements for Minimum Design Loads in Buildings and Other Structures (A58). National Bureau of Standards. United States Government Printing Office, Washington (1945) p 30.

[6] Green, Melvyn. Building Codes for Existing and Historic Buildings. John Wiley \& Sons, Inc., Hoboken (2012).

[7] Rossber, Jim and Leon, Roberto T. Evolution of Codes in the USA. National Earthquake Hazards Reduction Program (2013).

[8] Friedman, Donald. Historical Building Construction: Design, Materials \& Technology. W.W. Norton \& Company Inc., New York (2010).

[9] Reitherman. Earthquakes and Engineers. p 147-151.

[10] Derry, T.K. and Williams, T.I. A Short History of Technology from the Earliest Times to A.D. 1900. Dover Publications, New York, NY (1993) p 481-486.

[11] Kidder, Frank E. The Architect's and Builder's Pocket-Book. John Wiley \& Sons, New York (1908) p 1082.

[12] Reitherman. Earthquakes and Engineers. p 147-151.

[13] Kidder. The Architect's and Builder's Pocket-Book. p 1082.

[14] Trautwine, John C. The Civil Engineer's Pocket-Book. Renouf Publishing Co., Wallingford (1872). 
[15] Pocket Companion Containing Useful Information and Tables Appertaining to the Use of Steel. Carnegie Steel Company. Pittsburg (1903) p 58.

[16] Freitag, Joseph Kendall. Architectural Engineering with Especial Reference to High Building Construction. John Wiley \& Sons, New York (1909) p 282.

[17] Tobriner, Stephen. Bracing for Disaster: Earthquake-Resistant Architecture and Engineering in San Francisco, 1838-1933. Heyday Books, Berkeley (2006) p 166.

[18] Minimum Design Loads in Buildings and Other Structures (A58) p 30-32.

[19] Reitherman. Earthquakes and Engineers. p 109 \& 648.

[20] Minimum Design Loads in Buildings and Other Structures (A58) p 30-32.

[21] Reitherman. Earthquakes and Engineers. p 147-151.

[22] Reitherman. Earthquakes and Engineers. p 650.

[23] Reitherman. Earthquakes and Engineers. p 200.

[24] Pregnoff, M.V. Connections: EERI Oral History Series, Michael Pregnoff and John Rinner. Earthquake Engineering Institute, Oakland (1996) p.14-17.

[25] Freitag. Architectural Engineering. p 249.

[26] Kidder. The Architect's and Builder's Pocket-Book. p 1082-1083.

[27] Kidder, Frank E. and Nolan, Thomas. The Architects' and Builders' Handbook. John Wiley \& Sons, New York (1921) p 1171-1193.

[28] Freeman, John R. Earthquake Damage and Earthquake Insurance. McGraw-Hill Book Company, New York (1932) p. 172.

[29] Reitherman. Earthquakes and Engineers. p 200.

[30] Reitherman. Earthquakes and Engineers. p 223.

[31] Reitherman. Earthquakes and Engineers. p 161, 222

[32] Rossber. Evolution of Codes in the USA.

[33] Minimum Design Loads in Buildings and Other Structures (A58).

[34] Reitherman. Earthquakes and Engineers. p 33, 288.

[35] Dixon, Rick. The Florida Building Code - Florida's Response to Hurricane Risk. Presentation by Florida Building Commision (2009).

[36] Reitherman. Earthquakes and Engineers. p 272, 476

[37] SEAOC Seismology Committee. Recommended Lateral Force Requirements and Commentary. Structural Engineers Association of California (1974), p-7C.

[38] Reitherman. Earthquakes and Engineers. p 585.

[39] Reitherman. Earthquakes and Engineers. p 371.

[40] Dixon, Rick. The Florida Building Code - Florida's Response to Hurricane Risk.

[41] Knezevich, John W. Hurricane-Driven Building Code Enhancements. Structure Magazine (July 2017).

[42] FEMA. Hurricanes' Impact on Florida's Building Codes \& Standards. FEMA Mitigation Section Technical Services Branch (2005).

[43] Reitherman. Earthquakes and Engineers. p 585.

[44] Green. Building Codes for Existing and Historic Buildings.

[45] Rossber. Evolution of Codes in the USA.

[46] Housner, G.W. Historical View of Earthquake Engineering, Proceedings of the Eighth World Conference on Earthquake Engineering, San Francisco (1984). 